\title{
ETHICAL DEBATE ON ANIMAL RESEARCH
}

\section{Abu Sadat Mohammad Nurunnabi ${ }^{1}$, Rokhsana Dil Afroz ${ }^{2}$, Salman Nur Alam ${ }^{3}$}

1. Dr. Abu Sadat Mohammad Nurunnabi, Erasmus Mundus Master of Bioethics Student, Centre for Biomedical Ethics and Law, Katholieke Universiteit Leuven, Belgium. Email: shekhor19@yahoo.com (corresponding author)

2. Dr. Rokhsana Dil Afroz, Assistant Professor, Department of Pharmacology \& Therapeutics, Shaheed Suhrawardy Medical College, Dhaka, Bangladesh.

3. Salman Nur Alam, Graduate Student, Department of Pharmacy, University of Dhaka, Bangladesh.

ABSTRACT: Animal research or animal testing is done worldwide, where vertebrate animals, from zebrafish to non-human primates, millions in number are used annually. The practice is regulated to various degrees in different countries. Scientists and science authorities still have their arguments to justify animal testing. However, dialogues and protests are also evident against it. Awareness and campaign in recent years has made scientists and governments make statement that animal testing should cause as little suffering to animals as possible and that animal tests should only be performed where necessary. We should also look into the matter deeply and compassionately.

KEY WORDS: animal research, animal testing, vivisection, ethical debate, care, use of animals

INTRODUCTION: Animal research or animal testing is the use of non-human animals in experiments. However, animal experimentation, in vivo testing, and vivisection have similar denotations but different connotations. Literally, 'vivisection' means the "cutting up" of a living animal, and historically referred only to experiments that involved the dissection of live animals ${ }^{1}$. The term is occasionally used to refer pejoratively to any experiment using living animals; for example, the Encyclopædia Britannica defines 'vivisection' as "operation on a living animal for experimental rather than healing purposes; more broadly, all experimentation on live animals" ${ }^{2}$. The word has a negative connotation, implying torture, suffering and death ${ }^{3}$. The word 'vivisection' is preferred by those opposed to this research, whereas scientists typically use the term 'animal experimentation',

Supporters of the use of animals in experiments, such as the British Royal Society, argue that virtually every medical achievement in the $20^{\text {th }}$ century relied on the use of animals in some way ${ }^{6}$, with the Institute for Laboratory Animal Research of the U.S. National Academy of Sciences arguing that even sophisticated computers are unable to model interactions between molecules, cells, tissues, organs, organisms, and the environment, making animal research necessary in many areas ${ }^{7}$. However, animal rights organizations and some animal welfare groups, such as People for the Ethical Treatment of Animals (PETA) and British Union for the Abolition of Vivisection (BUAV) raised questions on the legitimacy of it, arguing that it is cruel, poor scientific practice, poorly regulated, that medical progress is being held back by misleading animal models, that some of the tests are outdated, that it cannot reliably predict effects in humans, that the costs outweigh the benefits, or that animals have an intrinsic right not to be used for experimentation $^{3,8}$. Hence, there exists a strong debate on animal research till date. 
HISTORY OF ANIMAL EXPERIMENTATION: The earliest references to animal testing are found in the writings of the Greeks in the $2^{\text {nd }}$ and $4^{\text {th }}$ centuries BC. Aristotle (384-322 BC) and Erasistratus (304-258 BC) were among the first to perform experiments on living animals ${ }^{9}$. Galen, a physician in $2^{\text {nd }}$ century Rome, dissected pigs and goats, and is known as the "father of vivisection" ${ }^{10}$. Avenzoar, an Arabic physician in $12^{\text {th }}$ century Moorish Spain, who also practiced dissection, introduced animal testing as an experimental method of testing surgical procedures before applying them to human patients ${ }^{11,12}$.

Animals have been used repeatedly through the history of biomedical research. The founders, in 1831, of the Dublin Zoo - the fourth oldest zoo in Europe, after Vienna, Paris, and London - were members of the medical profession, interested in studying the animals both while they were alive and when they were dead ${ }^{13}$. In the 1880 s, Louis Pasteur convincingly demonstrated the germ theory of medicine by inducing anthrax in sheep ${ }^{14}$. In the 1890 s, Ivan Pavlov famously used dogs to describe classical conditioning ${ }^{15}$. Insulin was first isolated from dogs in 1922, and revolutionized the treatment of diabetes ${ }^{16}$. On November 3, 1957, a Russian dog, Laika, became the first of many animals to orbit the earth. In the 1970s, antibiotic treatments and vaccines for leprosy were developed using armadillos ${ }^{17}$, then given to humans ${ }^{18}$. The ability of humans to change the genetics of animals took a giant step forwards in 1974 when Rudolf Jaenisch was able to produce the first transgenic mammal, by integrating DNA from the SV40 virus into the genome of mice ${ }^{19}$. This genetic research progressed rapidly and, in 1996, Dolly the sheep was born, the first mammal to be cloned from an adult cell ${ }^{20}$.

Toxicology testing became important in the $20^{\text {th }}$ century. In the $19^{\text {th }}$ century, laws regulating drugs were more relaxed. For example, in the U.S., the government could only ban a drug after a company had been prosecuted for selling products that harmed customers. However, in response to the Elixir Sulfanilamide disaster of 1937 in which the eponymous drug killed more than 100 users, the U.S. congress passed laws that required safety testing of drugs on animals before they could be marketed. Other countries enacted similar legislation ${ }^{21}$. In the $1960 \mathrm{~s}$, in reaction to the Thalidomide tragedy, further laws were passed requiring safety testing on pregnant animals before a drug can be sold $^{22}$.

HISTORICAL DEBATE: As the experimentation on animals increased, especially the practice of vivisection, so did criticism and controversy. In 1655, the advocate of Galenic physiology Edmund O'Meara said that "the miserable torture of vivisection places the body in an unnatural state"23, 24. O'Meara and others argued that animal physiology could be affected by pain during vivisection, rendering results unreliable. There were also objections on an ethical basis, contending that the benefit to humans did not justify the harm to animals ${ }^{24}$. Early objections to animal testing also came from another angle - many people believed that animals were inferior to humans and so different that results from animals could not be applied to humans ${ }^{24}$.

On the other side of the debate, those in favor of animal testing held that experiments on animals were necessary to advance medical and biological knowledge. Claude Bernard, known as the 'prince of vivisectors' ${ }^{8}$ and the father of physiology - whose wife, Marie Françoise Martin, founded the first anti-vivisection society in France in $1883^{25}$, wrote that "the science of life is a superb and dazzlingly lighted hall which may be reached only by passing through a long and ghastly kitchen" ${ }^{26}$. Arguing that "experiments on animals ... are entirely conclusive for the toxicology and hygiene of man ... the effects of these substances are the same on man as on animals, save for differences in degree" 27 , Bernard established animal experimentation as part of the standard scientific method. 
In 1896, the physiologist and physician Walter B. Cannon remarked the antivivisectionists as the second of the two types, as described by Theodore Roosevelt when he said, "Common sense without conscience may lead to crime, but conscience without common sense may lead to folly, which is the handmaiden of crime." ${ }^{28}$ These divisions between pro- and anti- animal testing groups first came to public attention during the brown dog affair in the early 1900s, when hundreds of medical students clashed with anti-vivisectionists and police over a memorial to a vivisected $\operatorname{dog}^{29}$.

In 1822, the British parliament passed the first animal protection law, followed by the Cruelty to Animals Act (1876), the first law specifically aimed at regulating animal testing, and in the United States, when Henry Bergh founded the American Society for the Prevention of Cruelty to Animals (ASPCA) in 1860s, with the American AntiVivisection Society (AAVS), founded in 1883, are noted as anti-animal testing approach ${ }^{30}$. However, in the USA the antivivisectionists' efforts were defeated in every legislature, as overwhelmed by the superior organization and influence of the medical community. However, their success came when Laboratory Animal Welfare Act was passed in $1966^{30}$.

SOME ETHICAL VIEWPOINTS: The ethical concerns raised by performing experiments on animals are subject to much debate, and viewpoints have shifted significantly over the $20^{\text {th }}$ century ${ }^{25}$. Disagreements remain about which procedures are useful for which purposes, as well as disagreements over which ethical principles apply to which species. The dominant ethical position worldwide is that achievement of scientific and medical goals using animal testing is desirable, so long as animal suffering and use is minimized ${ }^{24}$. Two special considerations are presented here for readers' understanding.

1. Pain and suffering: The extent to which animal testing causes pain and suffering, and the capacity of animals to experience and comprehend them, is the subject of much debate ${ }^{31,32}$.

According to the U.S. Department of Agriculture, in 2006 about 670,000 animals (57\%) (not including rats, mice, birds, or invertebrates) were used in procedures that did not include more than momentary pain or distress. About $420,000(36 \%)$ were used in procedures in which pain or distress was relieved by anesthesia, while $84,000(7 \%)$ were used in studies that would cause pain or distress that would not be relieved ${ }^{33}$.

In the UK, research projects are classified as mild, moderate, and substantial in terms of the suffering the researchers conducting the study say they may cause; a fourth category of "unclassified" means the animal was anesthetized and killed without recovering consciousness, according to the researchers. In December 2001, 1,296 (39\%) of project licenses in force were classified as mild, $1,811(55 \%)$ as moderate, $63(2 \%)$ as substantial, and $139(4 \%)$ as unclassified $^{34}$. There have, however, been suggestions of systemic underestimation of procedure severity ${ }^{35}$.

The idea that animals might not feel pain as human beings feel it traces back to the $17^{\text {th }}$ century French philosopher, René Descartes, who argued that animals do not experience pain and suffering because they lack consciousness ${ }^{1,36}$. Bernard Rollin, the principal author of two US federal laws regulating pain relief for animals, ${ }^{37}$ writes that researchers remained unsure into the 1980 s as to whether animals experience pain, and that veterinarians trained in the USA before 1989 were simply taught to ignore animal pain ${ }^{38}$. In his interactions with scientists and other veterinarians, he was regularly asked to "prove" that animals are conscious, and to provide "scientifically acceptable" grounds for claiming that they feel pain ${ }^{38}$. Carbone writes that the view that animals feel pain differently is now a minority view. Academic reviews of the topic are more equivocal, noting that although the argument that animals have at least simple conscious thoughts and feelings has strong support ${ }^{39}$, some critics 
continue to question how reliably animal mental states can be determined ${ }^{36,40}$. The ability of invertebrate species of animals, such as insects, to feel pain and suffering is also unclear ${ }^{41,42}$.

The defining text on animal welfare regulation, "Guide for the Care and Use of Laboratory Animals" defines the parameters that govern animal testing in the USA, stating that "... the ability to experience and respond to pain is widespread in the animal kingdom...Pain is a stressor and, if not relieved, can lead to unacceptable levels of stress and distress in animals ${ }^{\mathrm{N3}}$. The Guide also states that the ability to recognize the symptoms of pain in different species is vital in efficiently applying pain relief and that it is essential for the people caring for and using animals to be entirely familiar with these symptoms. On the subject of analgesics used to relieve pain, the Guide states " $\ldots$ the selection of the most appropriate analgesic or anesthetic should reflect professional judgment as to which best meets clinical and humane requirements without compromising the scientific aspects of the research protocol"43. Accordingly, all issues of animal pain and distress, and their potential treatment with analgesia and anesthesia, are required regulatory issues in receiving animal protocol approval.

2. Animal euthanasia: There is general agreement that animal life should not be taken wantonly, and regulations require that scientists use as few animals as possible ${ }^{44}$. However, while policy makers consider suffering to be the central issue and see animal euthanasia as a way to reduce suffering, others, such as the RSPCA, argue that the lives of laboratory animals have intrinsic value ${ }^{45}$. Regulations focus on whether particular methods cause pain and suffering, not whether their death is undesirable in itself ${ }^{46}$. The animals are euthanized at the end of studies for sample collection or post-mortem examination; during studies if their pain or suffering falls into certain categories regarded as unacceptable, such as depression, infection that is unresponsive to treatment, or the failure of large animals to eat for five days; ${ }^{47}$ or when they are unsuitable for breeding or unwanted for some other reason ${ }^{48}$.

The following methods of euthanizing laboratory animals are chosen to induce rapid unconsciousness and death without pain or distress ${ }^{43}$. The animal can be made to inhale a gas, such as carbon monoxide and carbon dioxide, by being placed in a chamber, or by use of a face mask, with or without prior sedation or anesthesia. Sedatives or anesthetics such as barbiturates can be given intravenously, or inhalant anesthetics may be used. Amphibians and fish may be immersed in water containing an anesthetic such as tricaine. Physical methods are also used, with or without sedation or anesthesia depending on the method. Recommended methods include decapitation (beheading) for small rodents or rabbits. Cervical dislocation (breaking the neck or spine) may be used for birds, mice, and immature rats and rabbits. Maceration (grinding into small pieces) is used on 1 day old chicks. High-intensity microwave irradiation of the brain can preserve brain tissue and induce death in less than 1 second, but this is currently only used on rodents. Captive bolts may be used, typically on dogs, ruminants, horses, pigs and rabbits. It causes death by a concussion to the brain. Gunshot may be used, but only in cases where a penetrating captive bolt may not be used. Some physical methods are only acceptable after the animal is unconscious. Electrocution may be used for cattle, sheep, swine, foxes, and mink after the animals are unconscious, often by a prior electrical stun. Pithing (inserting a tool into the base of the brain) is usable on animals already unconscious. Slow or rapid freezing, or inducing air embolism are acceptable only with prior anesthesia to induce unconsciousness $^{49}$.

Besides, a wide range of minority viewpoints exist. The view that animals have moral rights (animal rights) is a philosophical position proposed by Tom Regan, who argues that animals are beings with beliefs and desires, and as such are the "subjects of a life" with moral value and therefore moral rights ${ }^{50}$. Regan still sees ethical differences between killing human and non-human animals, and argues that to save the former it is permissible to kill the latter $^{50,51}$. Likewise, a 'moral dilemma' view suggests that avoiding potential benefit to humans is unacceptable on 
similar grounds, and holds the issue to be a dilemma in balancing such harm to humans to the harm done to animals in research ${ }^{51}$. In contrast, an abolitionist view in animal rights holds that there is no moral justification for any harmful research on animals that is not to the benefit of the individual animal ${ }^{36}$. Rollin argues that benefits to human beings cannot outweigh animal suffering, and that human beings have no moral right to use an animal in ways that do not benefit that individual ${ }^{52}$. Another prominent position is that of philosopher Peter Singer, who argues that there are no grounds to include a being's species in considerations of whether their suffering is important in utilitarian moral considerations ${ }^{51}$. However, recently the British government has taken the position to observe that the cost to animals in an experiment should be weighed against the gain in knowledge ${ }^{53}$.

SOME ALTERNATIVES TO ANIMAL RESEARCH: Scientists and governments state that animal testing should cause as little suffering to animals as possible, and that animal tests should only be performed where necessary. The ' 3 Rs', originally proposed by WMS Russell and RL Burch in $1959^{54}$, are guiding principles for the use of animals in research in most countries. Replacement refers to the preferred use of non-animal methods over animal methods whenever it is possible to achieve the same scientific aim. Reduction refers to methods that are facilitating the researchers to obtain comparable levels of information from fewer animals, or to obtain more information from the same number of animals. Refinement refers to methods that alleviate or minimize potential pain, suffering or distress, and enhance animal welfare for the animals still used. The 3-R approach has become the golden standard since it has been practiced by the EFPIA ${ }^{55}$, the Council of Europe Convention ETS 123 and most recently successfully been used in a report by an EC Community Research report 'Animal Welfare Committees in the European Research Area' ${ }^{56}$. As already mentioned, the Indian CPCSEA (Committee for the Purpose of Control and Supervision of Experiments on Animals) proposed and implemented a 4 R's set of principles - Replacement, Reduction, Refinement, Rehabilitation ${ }^{57}$. Rehabilitation is added to ensure proper attention to provide for rehabilitation and retirement centers for primates who have survived medical experiments for the sake of humans. Later in 2008, Hans-Martin Sass ${ }^{58}$ used this 4 R's model to propose an extended 7 R's model for the use in animal research ethics and corporate governance on a global and corporate level. The 7- $R$ approach includes the 'Replace, Reduce, Refine' principles and the Indian 'Rehabilitation' concept, but adds three more principles: 'Respect, Review, Relate' - either complementing or re-enforcing to the goals and methods already expressed in the use of the first three principles ${ }^{58}$. Respect refers to a special emphasis that should be laid on species-specific forms of harm, pain, distress, as they are related to the captivity environment and to the research itself. Moreover, Animal Welfare Committees (AWCs) are the instrument of choice to Review and to improve animal research on the local level and to reconcile different approaches and to set standards on the national or international level, i.e. thinking locally and act globally. Besides, to Relate issues, solutions, even uncertainties, as transparently and as simple and well reasoned as possible is always beneficial both for animal research and the corporate policy. Of course, in order to be effective, the 7-R model must be supported strongly by internal corporate policy, also not been confronted with financial or administrative shortcomings, if the ethically better option is considered to be the option of choice ${ }^{58}$.

Horst Spielmann, German Director of the Central Office for Collecting and Assessing Alternatives to Animal Experimentation, while describing in the 'Deutsche Welle' about Germany's progress in this area said, "Using animals in teaching curricula is already superfluous. In many countries, one can become a doctor, vet or biologist without ever having performed an experiment on an animal. ${ }^{159}$ However, there are efforts in many countries to find alternatives to using animals in education ${ }^{60}$. Moreover, alternative methods include positron emission tomography (PET), which allows scanning of the human brain in vivo, ${ }^{61}$ and comparative epidemiological studies of disease risk factors among human populations ${ }^{62}$. Several invertebrate systems are considered acceptable alternatives to animals in very early 
stage discovery screens ${ }^{63}$. Because of similarities between the innate immune system of insects and mammals, insects can replace mammals in certain types of studies. Drosophila melanogaster (a fruit fly) and Galleria mellonella (waxworm) have been particularly important for analysis of virulence traits of mammalian pathogens ${ }^{64,65}$. Waxworms and other insects have also proven valuable for the identification of pharmaceutical compounds with favorable bioavailability ${ }^{66}$.

CONCLUSION: Progressive changes have been made in recent years in the principles and practice of animal testing. Although such principles of care and use of animals and alternative propositions to animal research have been welcomed as a step forwards by some animal welfare groups ${ }^{67}$, they have also been criticized as both outdated by current research ${ }^{68}$, and of little practical effect in improving animal welfare ${ }^{69}$. However, by the time of reading this article, thousands of animals were sacrificed worldwide in the name of medical research or human welfare. We should think it very deeply and compassionately.

\section{REFERENCES:}

1. Carbone L. What animals want. Oxford: Oxford University Press; 2004.

2. Encyclopædia Britannica. 2010.

3. Croce P. Vivisection or Science? - an investigation into testing drugs and safeguarding health. Zed Books; 1999.

4. Paixão RL, Schramm FR. Ethics and animal experimentation: what is debated? Cadernos de saude publica / Ministerio da Saude, Fundacao Oswaldo Cruz, Escola Nacional de Saude Publica 1999; 15(Suppl 1): 99-110.

5. Yarri D. The ethics of animal experimentation. Oxford: Oxford University Press; 2005.

6. The use of non-human animals in research: a guide for scientists. UK: The Royal Society, UK; 2004.

7. Institute for Laboratory Animal Research. Science, Medicine, and Animals. USA: The National Academies Press; 2004.

8. Pound P, Ebrahim S, Sandercock P, Bracken MB, Roberts I, Reviewing Animal Trials Systematically (RATS) Group. Where is the evidence that animal research benefits humans? BMJ 2004; 328(7438): 514-7.

9. Cohen BJ, Loew FM. Historical perspectives in laboratory animal medicine. In: Fox JG, Cohen BJ, Loew FM. eds. Laboratory animal medicine. Florida: Academic Press; 1984.

10. Greek CR, Greek JS. Sacred cows and golden geese. New York: Continuum International Publishing; 2000.

11. Abdel-Halim RE. Contributions of Ibn Zuhr (Avenzoar) to the progress of surgery: a study and translations from his book Al-Taisir. Saudi Med J 2005; 26(9): 1333-9.

12. Abdel-Halim RE. Contributions of Muhadhdhab Al-Deen Al-Baghdadi to the progress of medicine and urology - a study and translations from his book Al-Mukhtar. Saudi Med J 2006; 27(11): 1631-41.

13. Costello J. The great zoo's who. Irish Independent. June 9, 2011.

14. Mock M, Fouet A. Anthrax. Annu Rev Microbiol 2001; 55: 647-71.

15. Windholz G. Pavlov as a psychologist - a reappraisal. Pavlov J Biol Sci 1987; 22(3): 103-12.

16. Gorden P. Non-insulin dependent diabetes—the past, present and future. Ann Acad Med Singap 1997; 26(3): 326-30.

17. Walgate R. Armadillos fight leprosy. Nature 1984; 291(5816): 527.

18. Scollard DM, Adams LB, Gillis TP, Krahenbuhl JL, Truman RW, Williams DL. The continuing challenges of leprosy. Clin Microbiol Rev 2006; 19(2): 338-81.

19. Jaenisch R; Mintz B. Simian virus 40 DNA sequences in DNA of healthy adult mice derived from preimplantation blastocysts injected with viral DNA. Proc Natl Acad Sci USA 1974; 71(4): 1250-4.

20. Wilmut I, Schnieke AE, McWhir J, Kind AJ, Campbell KH. Viable offspring derived from fetal and adult mammalian cells. Nature 1997; (6619): 810-3.

21. Taste of raspberries, taste of death. The 1937 Elixir Sulfanilamide Incident. FDA Consumer Magazine June 1981. Available from: http://www.fda.gov/oc/history [Accessed on June 29, 2011]. 
22. Burkholz H. Giving thalidomide a second chance. FDA Consumer (US Food and Drug Administration). Available from: http://www.fda.gov/oc/history [Accessed on July 01, 2011].

23. Ryder RD. Animal revolution: changing attitudes towards speciesism. Oxford: Berg Publishers; 2000.

24. Maehle $\mathrm{AH}$, Trohler $\mathrm{U}$. Animal experimentation from antiquity to the end of the eighteenth century: attitudes and arguments. In: Rupke NA. ed. Vivisection in historical perspective. London: Croom Helm; 1987.

25. Rudacille D. The Scalpel and the Butterfly: The Conflict. USA: Farrar Straus Giroux; 2000.

26. Bernard C. In sickness and in health: vivisection's undoing. The Daily Telegraph. November 2003.

27. Bernard C. An introduction to the study of experimental medicine. 1865. First English translation by Henry Copley Greene. USA: Macmillan; 1927: reprinted in 1949.

28. Nicoll CS. A physiologist's views on the animal rights/liberation movement. Physiologist 1991: 34(6): 303-15.

29. Mason P. The Brown Dog Affair - the story of a monument that divides the nation. London: Two Sevens Publishing; 1997.

30. Nurunnabi ASM, Afroz RD, Alam SN. Animal research in medical science: pros and cons. "Health Science" J PMC 2012; 2(1): 28-33.

31. Duncan IJ, Petherick JC. The implications of cognitive processes for animal welfare. J Anim Sci 1991; 69(12): 5017-22.

32. Curtis SE, Stricklin WR. The importance of animal cognition in agricultural animal production systems: an overview. J Anim Sci 1991; 69(12): 5001-7.

33. Report on enforcement of the animal welfare act. 2005. http://www.aphis.usda.gov/animal_welfare/downloads/awreports/awreport2005.pdf [Accessed on July 03, 2011].

34. The humane care and treatment of laboratory animals. National Association of Biomedical Research. Available from: http://www.nabr.org [Accessed on July 11, 2011].

35. Trull FL, Rich BA. More regulation of rodents [editorial]. Science 1999; 284(5419): 1463.

36. The ethics of research involving animals. Nuffield Council on Bioethics. Available from: http://www.nuffieldbioethics.org/animal-research [Accessed on July 01, 2011].

37. Rollin BE. Animal research: a moral science. Talking point on the use of animals in scientific research. EMBO reports 8,6 , 2007. p. 521-5.

38. Rollin BE. The unheeded cry: animal consciousness, animal pain, and science. New York: Oxford University Press; 1989.

39. Griffin DR, Speck GB. New evidence of animal consciousness. Anim Cogn 2004; 7(1): 5-18.

40. Allen C. Assessing animal cognition: ethological and philosophical perspectives. J Anim Sci 1998; 76(1): 42-7.

41. Lockwood JA. The moral standing of insects and the ethics of extinction. Florida Entomologist 1987; 70(1): 70-89.

42. DeGrazia D, Rowan A. Pain, suffering, and anxiety in animals and humans. Theor Med 1991; 12(3): $193-211$.

43. Guide for the Care and Use of Laboratory Animals. ILAR, National Research Council, USA. 1996.

44. Flecknell P. Replacement, reduction and refinement. ALTEX 2002; 19(2): 73-8.

45. Animal Procedures Committee: review of cost-benefit assessment in the use of animals in research. The Animal Procedures Committee. June 2003. p.46-7.

46. Carbone L. Euthanasia. In: Bekoff M, Meaney C. eds. Encyclopedia of animal rights and welfare. Greenwood Publishing.

47. Euthanasia Guidelines. Research animal resources, University of Minnesota.

48. Close B, et al. Recommendations for euthanasia of experimental animals: part-1. Lab Anim 1996; 30(4): 295.

49. AVMA Guidelines on Euthanasia. June 2007. Report of the AVMA Panel on Euthanasia. Available from: http://www.avma.org/resources/euthanasia.pdf [Accessed on July 01, 2011].

50. Maehle AH. Literary responses to animal experimentation in seventeenth- and eighteenth-century Britain. Med Hist 1990 , 34(1): 27-51.

51. Singer P. A companion to ethics. London: Blackwell; 1991.

52. Rollin BE. The moral status of animals and their use as experimental subjects. In: Kuhse H, Singer P. eds. A companion to bioethics. London: Blackwell; 1998.

53. Summary of House of Lords Select Committee on Animals In Scientific Procedures. House of Lords, July 16, 2002. Chapter 3: The purpose and nature of animal experiments. [Retrieved July 6, 2011].

54. Russell WMS, Burch RL. The principles of humane experimental technique. London: Methuen \& Co.; 1959. 
55. European Federation of Pharmaceutical Industries and Associations (EFPIA). Policy statement on the use of animals in research and development. March, 1999.

56. European Commission (EC). Animal welfare committees in the European research area. Luxemburg: 2005. EUR 21786.

57. Pereira S, Tettamanti M. Ahimsa and alternatives - the concept of the $4^{\text {th }}$ R; the CPCSEA in India. ALTEX 2005; 22(1): 36.

58. Sass HM. Animal in research: 7-R principles and corporate responsibility. EJAIB 2008; 18(3): 74-85.

59. Seeking an end to animal experimentation. Deutsche Welle. August 23, 2005; [Retrieved June 15, 2011].

60. Dalal R, et al. Replacement alternatives in education: animal-free teaching [Conference abstract]. Fifth World Congress on Alternatives and Animal Use in the Life Sciences. Berlin, August 2005.

61. What is a PET scan? How does a PET scan work? Available from: http://www.medicalnewstoday.com/articles/154877.php [Accessed on April 17, 2011].

62. Jiang J, Liu B, Nasca PC, Han W, Zou X, Zeng X, et al. Comparative study of control selection in a national population based case-control study: estimating risk of smoking on cancer deaths in Chinese men. Int J Med Sci 2009; 6: 329-337.

63. Waterfield NR, Sanchez-Contreras M, Eleftherianos I, Dowling A, Yang G, Wilkinson P, et al. Rapid Virulence Annotation (RVA): identification of virulence factors using a bacterial genome library and multiple invertebrate hosts. Proc Natl Acad Sci USA. 2008; 105(41): 15967-72.

64. Kavanagh K, Reeves EP. Exploiting the potential of insects for in vivo pathogenicity testing of microbial pathogens. FEMS Microbiol Rev 2004; 28(1): 101-12.

65. Antunes LCS, Imperi F, Carattoli A, Visca P. Deciphering the multifactorial nature of Acinetobacter baumannii pathogenicity. PLoS ONE 2011; 6(8): e22674.

66. Aperis G, Fuchs BB, Anderson CA, Warner JE, Calderwood SB, Mylonakis E. Galleria mellonella as a model host to study infection by the Francisella tularensis live vaccine strain. Microbes Infect 2007; 9(6): 729-34.

67. Kolar R. ECVAM: desperately needed or superfluous? - an animal welfare perspective. Altern Lab Anim 2002; 30(Suppl 2): 169-74.

68. Schuppli CA, Fraser D, McDonald M. Expanding the three Rs to meet new challenges in humane animal experimentation. Altern Lab Anim 2004; 32(5): 525-32.

69. Rusche B. The 3Rs and animal welfare - conflict or the way forward? ALTEX 2003; 20(Suppl 1): 63-76. 